\title{
El bolero como texto cultural
}

\author{
M. Ed. Teresita Villalobos Hernández
}

En este ensayo trataré de referirme no solo a los orígenes del bolero sino también a lo que representa para la cultura latinoamericana, toda vez que no se trata solo música, letra y baile, sino también de sentimiento y amor.

El bolero es un tema muy interesante, basta con mencionar la palabra para que esta nos mueve sentimientos muy profundos: quién no se ha enamorado con un bolero, y con las escenas de sueño, de realización y de deseo que evoca.

De ahí que consideremos que este género musical puede incorporarse como un material lingüístico para que los estudiantes extranjeros se acerquen a nuestra cultura y adquieran un aprendizaje más significativo y ameno.

En un programa de Radio Felicidad de Cuba, en el espacio "Amigos de los Sonidos del Mundo", donde le rindieron un homenaje al bolero, el rey de la música románti$\mathrm{ca}$, afirmaban que este género musical se inició hacia el año 1885. Originalmente, el bolero nace en España y es reinventado en Cuba, dada la gran influencia de la cultura ibérica durante el período de la colonia, y luego se extiende al área del Caribe y también a varios países hispanoamericanos, como: 
México, Colombia, Perú, Venezuela, Chile, Costa Rica entre otros. Luego, con el paso del tiempo, pasa a ser parte de la cultura popular de nuestros países, aunque nace en la cultura de la clase alta con la Ópera y la Zarzuela.

Desde el punto de vista de la semiótica, el bolero puede concebirse dentro de un análisis del estudio de los signos, de su estructura y su relación entre el significante y el concepto de significado.

En ese sentido, el bolero adquiere significatividad en diferentes momentos, como por ejemplo al abrazarse, cerrar los ojos, sentir el cuerpo del otro en una escena de fiesta, el espacio lúdico será nocturno, en bares, cantinas, salones de baile.

En efecto, su majestad el bolero, como lo llaman los amantes de este género musical, convierte sus significados en noches inolvidables, de copas y amaneceres románticos. En las letras de sus canciones, predominan los verbos que incitan a la persona a ceder o realizar un deseo, como por ejemplo: Júrame, bésame, mírame, óyeme, así como muchos más.

Una de sus particularidades es que se trata un texto abierto, que siempre se puede modificar, pues cada cantante le puede imprimir su estilo, sus gestos, también le puede agregar palabras, o sea, cambiar su texto, cambiar de género, pueden alargar las vocales. A veces, incluso, cortar las palabras y sobre todo modificar los tiempos.

Una de las virtudes del bolero es que no pasa de moda, cantantes que le dieron fama a éste, en la época de nuestros padres allá por la década de 1950, tales como Pedro Infante, Olga Guillot, Daniel Santos, Héctor Lavoe, Tito Rodríguez, Leo Marini, Lucho Gatica, Ray Tico, Gilberto Hernández y muchos más, que no son conocidos por las nuevas generaciones, pero que en la voz de los nuevos cantantes, vienen a ser conocidos para ellas, por ejemplo: Luis Miguel 
cuando canta "Reloj no marques las horas", el famoso bolero de Marini.

En el bolero, el cantante y su voz deben mantener una relación entre voces e instrumentos, sea que cante en forma individual o en trío, acompañado de una guitarra o un piano, logrando trasmitir mediante los gestos de su cuerpo todo el sentimiento que encierra la letra de la canción. El cantante debe transmitir todo el sentimiento que encierra la letra al público que lo escucha, es ahí donde radica su éxito.

Ahora bien, es importante hablar también sobre las herencias del bolero, especialmente de sus orígenes ibérico y africano que se instalan en la Isla de Cuba y el Caribe, y que le aportan tanto los instrumentos y ritmos africanos sobre todo por el contacto de los cuerpos-, como el legado verbal hispano. Por eso se habla de tres niveles en el texto: la música, de origen caribeño; la letra, de América; y su danza y discurso amoroso de España. Es decir, hay una mezcla de culturas en su origen, y quizá por ello tiene tanta aceptación en los países de habla hispana.

Por esta razón, el bolero nos sirve para enseñar sobre la cultura latinoamericana. Cuando hablamos sobre sus orígenes, debemos referirnos a cómo son el hombre y la mujer latinoamericana, cuáles son sus gustos musicales, qué tipo de baile les gusta, cómo perciben el amor y cómo se enamoran.

Los extranjeros que vienen a nuestro país tienen una idea de cómo son el hombre y la mujer como pareja, tienen el famoso concepto del latin lover, y haciendo uso del bolero podemos enseñar cuáles son los mitos y realidades sobre esa concepción. Muchas de las letras describen el comportamiento de una pareja, cuáles son sus sentimientos de amor, desilusión o infidelidad, de manera que nos permiten introducir estos temas como parte del proceso de enseñanza y aprendizaje en el aula. 
Una de las características que se puede abordar en este tema es la interculturalidad latinoamericana ya que por medio del bolero, podemos enseñar acerca de las diferentes culturas, por ejemplo de Cuba, Puerto Rico, México, Perú, Argentina, Costa Rica, Chile y otros países; en ellos encontramos una mezcla de culturas según su origen, su ritmo y letra que reflejan el cómo es la cotidianidad del latinoamericano en el plano romántico.

Ahora bien, otra característica del bolero es que en él encontramos la presencia del arte de declamar: varios cantantes no solo cantan su letra sino que también van combinado la declamación, esto viene a darle un estilo aún más romántico. Un ejemplo de esto es cuando escuchamos a Toña la Negra cantando "Amor perdido" y a la mitad de la canción comienza a declamar:

"Hoy me convenzo que de tu parte

Nunca fuiste mío, ni yo para ti,

Ni tú para mi, ni yo para ti.

Todo fue un juego, no más, en la apuesta

Yo puse y perdí..."

Y luego continúa cantando hasta terminar, esto le da una connotación más romántica y la atención del público es aún mayor.

El bolero también tiene la capacidad de adaptarse a cualquier época y ritmo, los podemos escuchar al ritmo de mambo, al ritmo de ranchera, de feeling, del danzón, la guaracha y el chachachá. Por eso escuchamos cantantes como Agustín Lara, especialista en boleros, cantar "Amor de mis amores" al ritmo de chachachá, o al tenor Andrea Bocelli cantar "Bésame mucho" usando un ritmo diferente.

En nuestra época, el ritmo más usado es el llamado feeling, que es el de contacto, el de bailar más pegados, cuerpo 
con cuerpo, como en las canciones de Armando Manzanero, o de Gilberto Hernández con el bolero costarricense "Noche inolvidable", del autor Ricardo Mora, que también es interpretada por el grupo nacional Vía Libre en los años 1970.

Según la disciplina del psicoanálisis fundada por Sigmund Freud, este es un método de investigación que consiste en evidenciar la significación inconsciente de las palabras, actos, producciones imaginarias (sueños, fantasías, delirios) de un individuo. Este método se basa principalmente en las asociaciones libres del sujeto, que garantizan la validez de la interpretación.

En el bolero, la materialidad simbólica del texto se representa en el binomio cuerpo -palabra, es decir, se juntan la voz, el movimiento, el baile. De tal manera que esta dualidad hace que dos personas, inclusive sin conocerse y por medio del baile, se unan y enlacen su cuerpo al ritmo de la música, hasta despertar fantasías eróticas.

Cuando decimos que la escena del bolero se realiza en un salón de baile, los actores que los acompañan son los que aplauden, los que bailan, los que cantan y los que gritan, de tal forma que este género musical viene a ser un drama con una relación amorosa entre el público y el cantante.

Este tema nos permite abordarlo, en el contexto de la enseñanza y aprendizaje, desde su historia, orígenes, antecedentes, sensaciones, simbolismos, espacio lúdico, todo ello integrado a la cultura. Por medio de él viajamos en el tiempo, en el espacio, en nuestras vidas y la de las nuevas generaciones, que sueñan y recuerdan los bailes y las noches inolvidables al ritmo del bolero.

En este ensayo he querido trasmitir mi pasión por el bolero. Aunque no soy una experta en este tema, sí me considero una estudiosa y amante del bolero, ya que crecí escuchando estas canciones a mi madre, de quién aprendí de memoria las letras y música de ellas. 
El bolero une a las personas en sus vivencias y la herencia cultural, al tiempo que nos transmite mensajes de amor, de odio, de fracaso, de infidelidad, soledad y tristeza, pero al fin y al cabo, son recuerdos inolvidables que nooo volverán... 